\title{
Binding mechanism of halide ions to bovine serum albumin and hemoglobin: investigated by ion selective-electrode
}

\author{
Gongke Wang, Wen Tang, Xiaoxiao Hao, Changling Yan, Yan Lu* \\ School of Chemistry and Environmental Science, Henan Normal University, Xinxiang, China; \\ *Corresponding Author: wanggongke@126.com
}

Received 10 November 2010; revised 8 January 2011; accepted 16 February 2011.

\begin{abstract}
The binding mechanism of the interactions of halide ions $\left(\mathrm{F}^{-}, \mathrm{Br}^{-}\right.$and $\left.\mathrm{I}^{-}\right)$with bovine serum albumin (BSA) and hemoglobin ( $\mathrm{Hb}$ ) were studied at different temperatures, by using ion-selective electrodes. The experimental data were treated according to Klotz equation, and the number of binding sites and the binding constants were determined. The results show that the binding sites of $\mathrm{F}^{-}$on protein molecules are more than those of $\mathrm{Br}^{-}$and $\mathrm{I}^{-}$. Additionally, the number of the binding sites for halide ions on protein molecules increases with increasing temperature. This study also indicates that the binding constants for the interactions of halide ions with proteins gradually decrease as the size of halide ions and temperature increases. These behaviors were reasonably interpreted with the structural and thermodynamic factors. The thermodynamic functions at different temperatures were calculated with thermodynamic equations, and the enthalpy change for the interactions were also determined by isothermal titration calorimetry (ITC) at $298.15 \mathrm{~K}$, which indicate that the interactions of halide ions with proteins are mainly electrostatic interaction.
\end{abstract}

Keywords: Binding Mechanism; Interaction; Ion-Selective Electrode; Bovine Serum Albumin; Hemoglobin

\section{INTRODUCTION}

Since the interactions of small anions with protein are very important in their transportation and distribution processes in biological systems, it is helpful to study these interactions to understand the nature of the transportation and distribution processes. The capacity of a protein binding anions is mainly dependent on the chemical and structural properties of protein. In addition, the $\mathrm{pH}$ value of the solution, the ionic size, the ionic charge and the ionic concentration are also the influencing factors $[1,2]$. Bovine serum albumin (BSA) and hemoglobin $(\mathrm{Hb})$ have high affinities for various ligands. There have been relatively few studies on $\mathrm{Hb}$ [3], but more on BSA [4-9]. Although the amino acid composition and sequence of BSA which are important in its conformational analysis are now known [10], the nature of the binding of anions to proteins is not yet well interpreted. Equilibrium dialysis and UV-visible spectrophotometry have been used to study the binding of fluoride ion to BSA and obtained significant binding [11-13]. Peters [14] and Carter [15] have reviewed the studies on the binding of various ligands to serum albumin, respectively, expounding the binding sites of small organic molecules, fatty acid compounds with long side chain and metal ions on serum albumin molecule.

Ion-selective electrodes are useful tools to study the binding of ions to protein in aqueous and non-aqueous solutions, which can obtain accurate data for the binding of ions at low concentrations. Luehrs and Johnson studied the binding of $\mathrm{F}^{-}$to ovalbumin (OVA) by using ion-selective electrode and obtained the thermodynamic binding constant [16]. Sideris et al. studied the interaction of diflunisal ion and cyclodextrins with ion-selective electrode and discussed the cooperative binding between them [17]. Ayranci and Duman studied the binding of $\mathrm{F}^{-}, \mathrm{Br}^{-}$and $\mathrm{I}^{-}$to BSA with ion-selective electrodes. They calculated the binding sites and stepwise constants and interpreted the influence of charge on the binding sites $[18,19]$. Investigating the effect of temperature on the interactions between ions and proteins is also very important, which can help people to understand the nature of the interactions. However, few studies In this aspect have been reported. The objective of this work is to investigate the binding of $\mathrm{F}^{-}, \mathrm{Br}^{-}$and $\mathrm{I}^{-}$to 
BSA and Hb by using ion-selective electrodes. The emphasis is to study the effects of temperature on the interactions of halide ions with proteins, and discuss the nature of the interactions with thermodynamic and structural viewpoints according to hofmaister series [20].

\section{MATERIALS AND METHODS}

\subsection{Reagents and Chemicals}

BSA and $\mathrm{Hb}$ (from bovine blood) were purchased from Sigma Chemical Co. without further purified before use. The standard regents of $\mathrm{NaF}, \mathrm{KBr}$ and $\mathrm{KI}$ were from the First Chemical Co. of Shanghai, and $\mathrm{NaNO}_{3}$ was from the Hongxing Chemical Co of Beijing. All of the chemical reagents were kept over $\mathrm{P}_{2} \mathrm{O}_{5}$ in a desiccator prior to use, and weighed on an electronic balance (Sartorius, Germany) with a sensitivity of $10^{-5}$ g. All solutions were prepared in acetate buffers of $\mathrm{pH} 5.68$ and ionic strength $0.10 \mathrm{~mol} \cdot \mathrm{L}^{-1}$. Doubly distilled water was used throughout.

A model of 201 fluoride ion-selective electrode, 302 Bromide ion-selective electrode and 303 iodide ion-selective electrode, which were purchased from Jiangsu Jiangfen Electroanalytical Instrument Co. LTD, were used for the studies of $\mathrm{F}^{-}, \mathrm{Br}^{-}$and $\mathrm{I}^{-}$, respectively. A model of 802 single-junction calomel electrode was used as the reference electrode for $\mathrm{F}^{-}$studies. For the studies of $\mathrm{Br}^{-}$and $\mathrm{I}^{-}$, a model of 217 double-junction calomel electrode was used as the reference electrode. The two reference electrodes were purchased from Shanghai Ruosull Technology Co. LTD. The measurements of the potentials were made by using a PXSJ-216 Ion Analyzer which was from Shanghai Leici Instrument Co., with a readability of $\pm 0.1 \mathrm{mV}$.

Titrations for binding experiments were carried out with a Proline Mechanical Single-Channel Pipettors (Shanghai, China). All measurements were carried out in a 50ml double-walled glass cell which was immersed in a model of DC-2006 Circulating Thermostat (Shanghai, China) with the precision of $\pm 0.01 \mathrm{~K}$. The sample solution was continuously stirred using a magnetic stirrer.

\subsection{Construction of Calibration Equations of the Ion-Selective Electrodes}

The pair of electrodes was immersed in $20 \mathrm{ml} \mathrm{NaF}$ solutions of different concentrations. The potential values $(\mathrm{mV})$ were recorded and measured after stabilization $( \pm 0.1 \mathrm{mV})$. The potential values were plotted against logarithm of $\mathrm{F}^{-}$concentration according to the Nernst equation, and the calibration curve was determined by least-squares fitting of the Nernst equation to the experimental data. The same procedure was followed for the construction of calibration equations of $\mathrm{Br}^{-}$and $\mathrm{I}^{-}$ selective electrodes.

\subsection{Studies on the Binding of Halide lons to BSA and $\mathrm{Hb}$ by the lon-Selective Electrode}

The pair of electrodes were immersed in $25 \mathrm{ml} 2 \times$ $10^{-4} \mathrm{~mol} \cdot \mathrm{L}^{-1}$ protein solution. A $6 \times 10^{-3} \mathrm{~mol} \cdot \mathrm{L}^{-1} \mathrm{stan}-$ dard NaF solution was used as a titrant. After the potential was stabilized, small volumes (about $2 \mathrm{ml}$ ) of the titrant were added. After each addition, the potential values were recorded by waiting sufficient time for equilibration. The potential values were converted into concentrations of free $\mathrm{F}^{-}$by use of the previously obtained calibration equation of $\mathrm{F}^{-}$. The total amount of bound $\mathrm{F}^{-}$ was calculated as the difference between the amount of total $\mathrm{F}^{-}$added and the amount of free $\mathrm{F}^{-}$measured at equilibrium. Then the average number of bound anions of each protein molecules, $r$, can be obtained with the total amount of bound $\mathrm{F}^{-}$and the concentration of protein. The same procedure was followed for the binding experiments of the other two ions, $\mathrm{Br}^{-}$and $\mathrm{I}^{-}$.

\section{RESULTS AND DISCUSSION}

\subsection{Binding Sites of Halide Ions on Protein Molecules}

Klotz has given the relation of the average number of bound anions of each protein molecules $(r)$ and the concentration of free anion in the binding equilibrium ([A]) as follows [8]

$$
r=\left(\frac{1}{n k}\right) \frac{1}{[\mathrm{~A}]}+\frac{1}{n}
$$

where $n$ is the number of binding sites and $k$ is the binding constant. We plotted $1 / r$ against $1 /[\mathrm{A}]$ for the systems studied in this paper and represented these plots in Figures 1-6.

There are obvious linear relations in these figures, which indicate that Eq.1 is in good agreement with the binding model of the interactions between halide ions and proteins. Fitting the data of $1 / r$ and $1 /[\mathrm{A}]$ according to Eq.1 by using a least-square method, we obtained the regressing equations and the binding parameters ( $n$ and $k$ ) which are presented in Table 1.

From Table 1, we can see that the numbers of binding sites for $\mathrm{Br}^{-}$and $\mathrm{I}^{-}$on BSA and $\mathrm{Hb}$ molecules are, in all case, almost the same value, while that of $\mathrm{F}^{-}$are greater. Since these ions all have single negative charge, their difference is only in the ionic size. $\mathrm{F}^{-}$has the least size and the largest charge density among these ions, so its ability of biding with the weaker polar groups on protein 


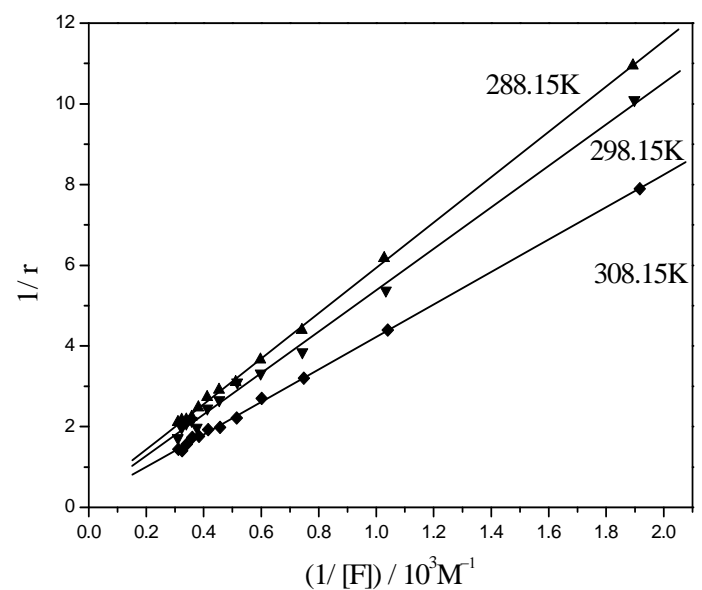

Figure 1. The plot for the molar ratio of BSA to bound $\mathrm{F}^{-}, 1 / r$, versus the reciprocal of concentration of free $\mathrm{F}^{-}, 1 /\left[\mathrm{F}^{-}\right]$, at different temperatures in acetate buffer solutions of $\mathrm{pH} 5.68$.

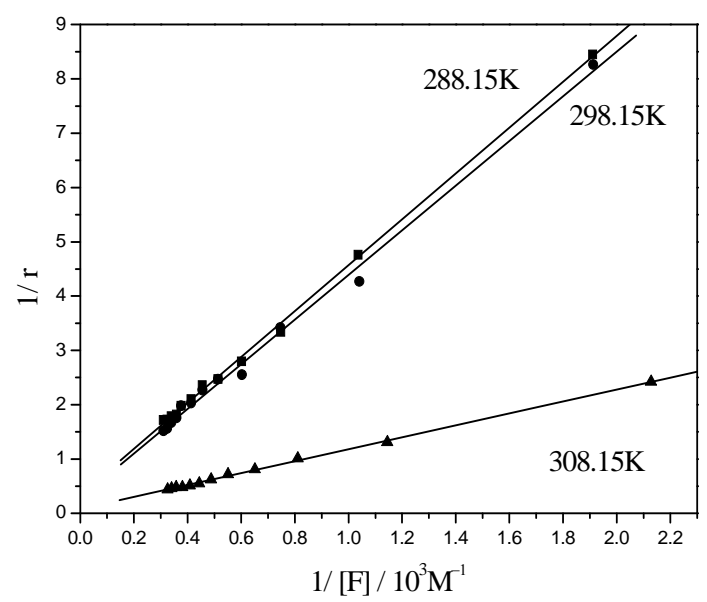

Figure 2. The plot for the molar ratio of $\mathrm{Hb}$ to bound $\mathrm{F}^{-}, 1 / r$, versus the reciprocal of concentration of free $\mathrm{F}^{-}, 1 /\left[\mathrm{F}^{-}\right]$, at different temperatures in acetate buffer solutions of $\mathrm{pH}$ 5.68.

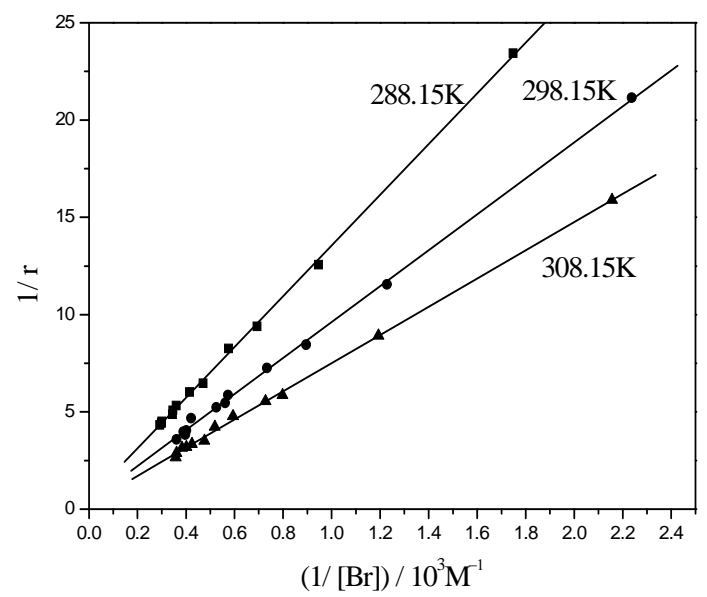

Figure 3. The plot for the molar ratio of BSA to bound $\mathrm{Br}^{-}, 1 / r$, versus the reciprocal of concentration of free $\mathrm{Br}^{-}, 1 /\left[\mathrm{Br}^{-}\right]$, at different temperatures in acetate buffer solutions of $\mathrm{pH}$ 5.68.

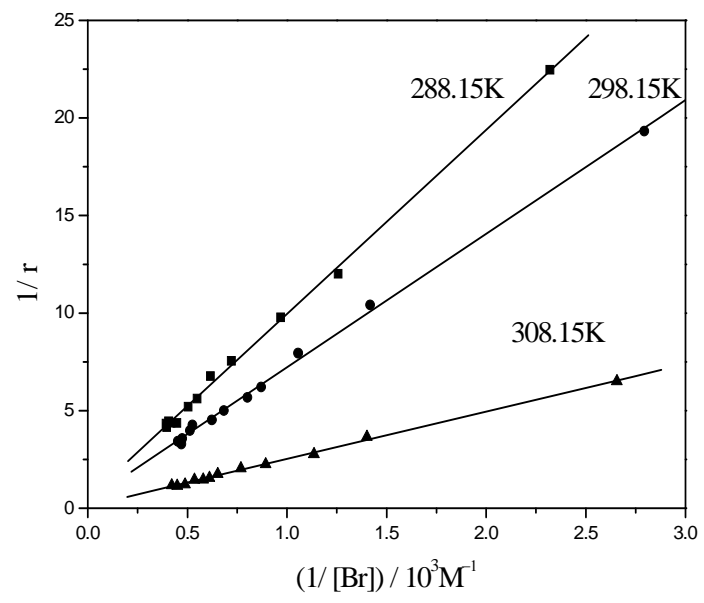

Figure 4. The plot for the molar ratio of $\mathrm{Hb}$ to bound $\mathrm{Br}^{-}, 1 / r$, versus the reciprocal of concentration of free $\mathrm{Br}^{-}, 1 /\left[\mathrm{Br}^{-}\right]$, at different temperatures in acetate buffer solutions of $\mathrm{pH}$ 5.68.

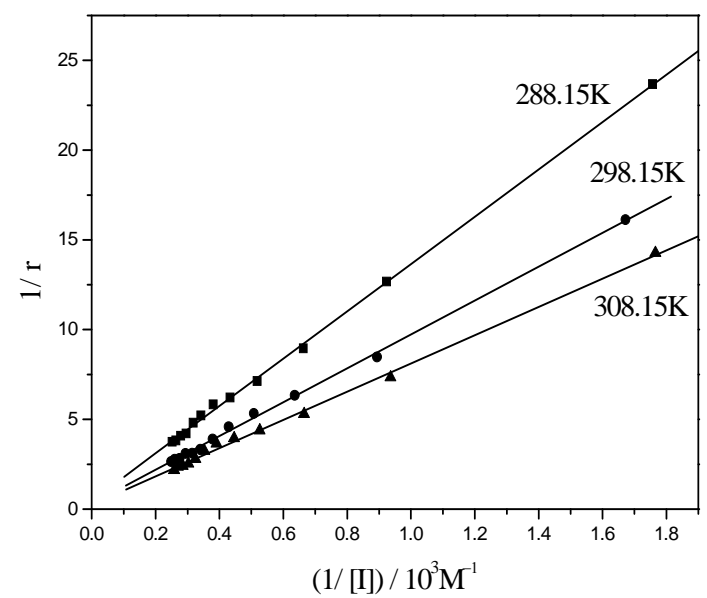

Figure 5. The plot for the molar ratio of BSA to bound $\mathrm{I}^{-}, 1 / r$, versus the reciprocal of concentration of free $\mathrm{I}^{-}, 1 /\left[\mathrm{I}^{-}\right]$, at different temperatures in acetate buffer solutions of $\mathrm{pH} 5.68$.

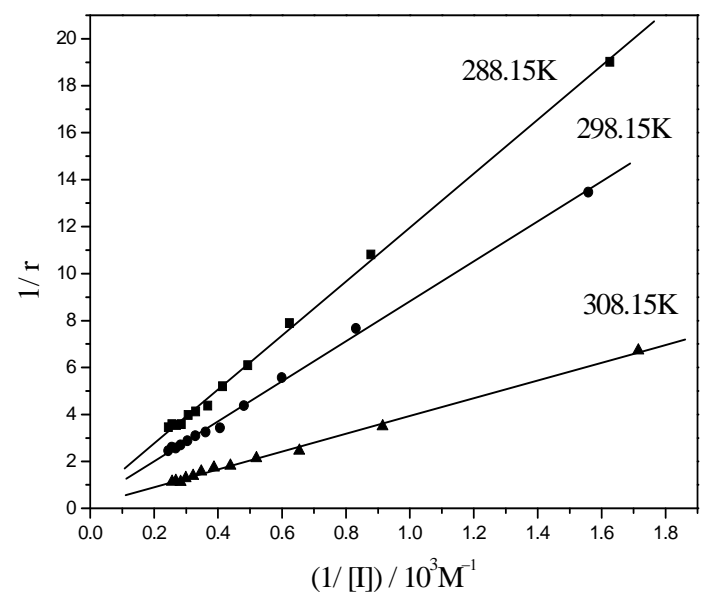

Figure 6. The plot for the molar ratio of $\mathrm{Hb}$ to bound $\mathrm{I}^{-}, 1 / r$, versus the reciprocal of concentration of free $\mathrm{I}^{-}, 1 /\left[\mathrm{I}^{-}\right]$, at different temperatures in acetate buffer solutions of $\mathrm{pH} 5.68$. 
Table 1. Regression equations, fitting parameters (number of binding sites, $n$, and binding constants, $k$ ) and correlation coefficients of Eq.1 for the interactions of halide ions with BSA and $\mathrm{Hb}$ in acetate buffer solutions measured by ion-selective electrode method at different temperatures.

\begin{tabular}{|c|c|c|c|c|c|}
\hline & $\mathrm{T} / \mathrm{K}$ & Regression equations & $n$ & $k /\left(\mathrm{L} \cdot \mathrm{mol}^{-1}\right)$ & $R^{\mathrm{a}}$ \\
\hline & \multicolumn{5}{|l|}{$\mathrm{F}^{-}$} \\
\hline & 288.15 & $1 / r=0.313+5.622 \times 10^{-3}\left(1 /\left[\mathrm{F}^{-}\right]\right)$ & 3.19 & 59.2 & 0.9997 \\
\hline \multirow[t]{3}{*}{ BSA } & 298.15 & $1 / r=0.246+5.137 \times 10^{-3}\left(1 /\left[\mathrm{F}^{-}\right]\right)$ & 4.07 & 48.8 & 0.9982 \\
\hline & 308.15 & $1 / r=0.197+4.026 \times 10^{-3}\left(1 /\left[\mathrm{F}^{-}\right]\right)$ & 5.08 & 49.8 & 0.9995 \\
\hline & 288.15 & $1 / r=0.342+4.226 \times 10^{-3}\left(1 /\left[\mathrm{F}^{-}\right]\right)$ & 2.92 & 78.7 & 0.9993 \\
\hline \multirow[t]{4}{*}{$\mathrm{Hb}$} & 298.15 & $1 / r=0.279+4.111 \times 10^{-3}\left(1 /\left[\mathrm{F}^{-}\right]\right)$ & 3.58 & 61.0 & 0.9975 \\
\hline & 308.15 & $1 / r=0.082+1.098 \times 10^{-3}\left(1 /\left[\mathrm{F}^{-}\right]\right)$ & 12.17 & 75.8 & 0.9993 \\
\hline & \multicolumn{5}{|l|}{$\mathrm{Br}^{-}$} \\
\hline & 288.15 & $1 / r=0.513+13.039 \times 10^{-3}\left(1 /\left[\mathrm{Br}^{-}\right]\right)$ & 1.95 & 1.95 & 0.9996 \\
\hline \multirow[t]{3}{*}{ BSA } & 298.15 & $1 / r=0.368+9.244 \times 10^{-3}\left(1 /\left[\mathrm{Br}^{-}\right]\right)$ & 2.72 & 2.72 & 0.9993 \\
\hline & 308.15 & $1 / r=0.255+7.249 \times 10^{-3}\left(1 /\left[\mathrm{Br}^{-}\right]\right)$ & 3.92 & 3.92 & 0.9993 \\
\hline & 288.15 & $1 / r=0.505+9.447 \times 10^{-3}\left(1 /\left[\mathrm{Br}^{-}\right]\right)$ & 1.98 & 52.8 & 0.9991 \\
\hline \multirow[t]{4}{*}{$\mathrm{Hb}$} & 298.15 & $1 / r=0.371+6.847 \times 10^{-3}\left(1 /\left[\mathrm{Br}^{-}\right]\right)$ & 2.70 & 49.0 & 0.9988 \\
\hline & 308.15 & $1 / r=0.097+2.427 \times 10^{-3}\left(1 /\left[\mathrm{Br}^{-}\right]\right)$ & 10.31 & 46.5 & 0.9989 \\
\hline & $\mathrm{I}^{-}$ & & & & \\
\hline & 288.15 & $1 / r=0.475+13.181 \times 10^{-3}\left(1 /\left[\mathrm{I}^{-}\right]\right)$ & 2.11 & 37.9 & 0.9995 \\
\hline \multirow[t]{3}{*}{ BSA } & 298.15 & $1 / r=0.301+9.433 \times 10^{-3}\left(1 /\left[I^{-}\right]\right)$ & 3.32 & 35.2 & 0.9993 \\
\hline & 308.15 & $1 / r=0.258+7.863 \times 10^{-3}\left(1 /\left[I^{-}\right]\right)$ & 3.88 & 31.6 & 0.9986 \\
\hline & 288.15 & $1 / r=0.469+11.492 \times 10^{-3}\left(1 /\left[\mathrm{I}^{-}\right]\right)$ & 2.13 & 43.7 & 0.9992 \\
\hline \multirow[t]{2}{*}{$\mathrm{Hb}$} & 298.15 & $1 / r=0.303+8.517 \times 10^{-3}\left(1 /\left[I^{-}\right]\right)$ & 3.30 & 39.5 & 0.9988 \\
\hline & 308.15 & $1 / r=0.146+3.787 \times 10^{-3}\left(1 /\left[I^{-}\right]\right)$ & 6.85 & 37.3 & 0.9984 \\
\hline
\end{tabular}

${ }^{\mathrm{a}}$ The correlation coefficient.

is stronger than that of $\mathrm{Br}^{-}$and $\mathrm{I}^{-}$. For the systems studied here, it is found that the number of the binding sites for $\mathrm{F}^{-}, \mathrm{Br}^{-}$and $\mathrm{I}^{-}$increases with increasing temperature. The secondary structure for the two proteins should be responsible for this kind of behavior. It has been reported that there is $65 \% \alpha$-helix content for BSA, and $70 \%$ for $\mathrm{Hb}$ [14]. Ikedo et al. have indicated that the $\alpha$-helix content of BSA was gradually lowered with increasing temperature [21]. The decrease of $\alpha$-helix content will make the peptidic chains unfolded, so that the latent binding sites in the $\alpha$-helix structure are accessible by halide ions. Therefore, the number of the binding sites will be greater with increasing temperature. Additionally, it is found that the numbers of the binding sites for $\mathrm{F}^{-}, \mathrm{Br}^{-}$and $\mathrm{I}^{-}$on $\mathrm{Hb}$ molecules are much lager than that of BSA molecules at $308.15 \mathrm{~K}$. This indicates that the secondary structure of $\mathrm{Hb}$ is more unstable than that of BSA at higher temperature. It is equivalent to say that the decrease of $\alpha$-helix content is quicker and the unfolding of the peptidic chains is greater with increasing temperature. As the temperature increases, however, the thermal motion of molecules and ions will be more rapid, which will make that the binding of halide ions to proteins is more difficulty. Although there is the unfavorable influence on the interactions between ions and proteins, the numbers of binding sites still increase with increasing temperature. This indicates that the change of secondary structure for the proteins is the main effect on the number of binding sites of halide ions to proteins as temperature increases.

\subsection{Intrinsic Binding Constant}

The intrinsic binding constants of the interactions of $\mathrm{F}^{-}, \mathrm{Br}^{-}$and $\mathrm{I}^{-}$with BSA and $\mathrm{Hb}$ at $288.15 \mathrm{~K}, 298.15 \mathrm{~K}^{-}$ and $308.15 \mathrm{~K}$ were presented in Table 1. It can be summed up in two rules: 1) the binding constants for the interactions of halide ions with the two proteins gradually decrease as the size of halide ions increases; 2) the binding constants gradually decrease with increasing tem- 
perature (except the systems containing $\mathrm{F}^{-}$). It is known that the binding of halide ions to proteins is mainly with the electrostatic interaction as described above. Protein molecules and halide ions are highly hydrated, and the hydration structures will be partially destroyed by the electrostatic interactions between them. It is the incompletely hydrated halide ions that can bind with the polar groups on protein molecules. As the size of ions increases, the charge density will decrease, and the electrostatic interactions of ions with the polar groups on protein molecules will also be relatively weak, which leads to the binding constants decreasing. At the same time, the thermal motion of halide ions and protein molecules will be more rapid with increasing temperature, which will make the stability of the complex of anion-protein lowered. Therefore, the binding constants will be decreased as temperature increase. This is in accord with what Chengnong Yan and co-workers have reported [22].

It is worth mentioning that the binding constants of the interactions of $\mathrm{F}^{-}$with BSA and with $\mathrm{Hb}$ first decrease and then increase when the temperature increases from $298.15 \mathrm{~K}$ to $308.15 \mathrm{~K}$, which is not consistent with the above rules. The major cause of the behavior is its own characteristics of $\mathrm{F}^{-}$. In fact, the ionic hydration structure includes two layers. The first layer which is close to the ions has the compact structure, is also called chemical hydration layer. The second layer next to the first has the unfirm structure, which is also called physical hydration layer. The size of $\mathrm{F}^{-}$is the least among the three halide ions, so its charge density is the largest, and its chemical hydration structure is the thickest. When the temperature is lower, the chemical hydration layer of the ions is difficult to be destroyed completely by the interactions of ions with proteins. However, as the temperature increases gradually, the thermal motion of ions and molecules not only result in the instability of the binding of ions to proteins, but also the instability of the ionic hydration structure. The latter effect will make the water molecules depart from the ions easily. Therefore, this effect will make the binding of ions to proteins stronger and the binding constants greater. The complexity of the change of the binding constants for the interaction of $\mathrm{F}^{-}$ with the two proteins is caused by the competition of the above two effects.

\subsection{Thermodynamic Studies}

Since the interactions between anions and proteins are rather complicated, the nature of the binding of anions is not yet clearly known [19]. According to the study of the interactions of ions with amino acids [23], the interactions of ions and small molecules with proteins can also be considered to be composed of three effects: 1 ) elec- trostatic interaction; 2) partial desolvation of solutes; 3) solvent reorganization effect. The electrostatic interaction is mainly occurring between ions and the polar groups of proteins. This kind of interaction is exothermic and will give negative contribution to the enthalpic function $\left(\Delta H^{\theta}\right)$. Since protein molecules and anions are hydrated in aqueous solutions, the binding of anions to proteins should be accompanied with the partial desolvation of solutes caused by the cosphere overlap of solvation layer of solutes. The partial desolvation of solutes is endothermic, and will give positive contribution to $\Delta H^{\theta}$. The binding of anions to proteins will, of course, give negative contribution to entropic function $\left(\Delta S^{\theta}\right)$. However, the partial desolvation of solutes accompanied with the binding, which makes the structure of water molecules of solvation layer destructive to a certain extent, also changes the structural water molecules into free water molecules. Therefore, the partial desolvation effect will give positive contribution to $\Delta S^{\theta}$. As for the contribution of the solvent reorganization effect to $\Delta H^{\theta}$ and $\Delta S^{\theta}$, it should be quite complex for different systems. In general, the solvent reorganization effect gives positive contribution if it destroys the solvent structure. On the contrary, it will give negative contribution if it enhances the solvent structure. The values of $\Delta H^{\theta}$ and $\Delta S^{\theta}$ for the whole process should be mainly determined by the relative contribution of the three effects.

The intrinsic binding constants for the interactions of $\mathrm{F}^{-}, \mathrm{Br}^{-}$and $\mathrm{I}^{-}$with BSA and with $\mathrm{Hb}$ at different temperatures were obtained as presented in Table 1. With the thermodynamic relation

$$
\Delta G^{\theta}=-R T \ln k .
$$

Gibbs free energy $\left(\Delta G^{\theta}\right)$ can be calculated. $\Delta H^{\theta}$ may be regarded as a constant when the temperature changes little, and can be determined by Van't Hoff equation

$$
\Delta H^{\theta}=\frac{-R(d \ln k)}{d(1 / T)}
$$

$\Delta S^{\theta}$ of the binding will be given as the following relation

$$
\Delta S^{\theta}=T\left(\Delta H^{\theta}-\Delta G^{\theta}\right) .
$$

The thermodynamic functions for the interactions of $\mathrm{F}^{-}, \mathrm{Br}^{-}$and $\mathrm{I}^{-}$with BSA and with $\mathrm{Hb}$ at $288.15 \mathrm{~K}$, 298.15 K and 308.15 K, which were calculated with Eqs. 2-4, are presented in Table 2.

Table 2 shows that the values of $\Delta G^{\theta}$ for the interactions of $\mathrm{F}^{-}, \mathrm{Br}^{-}$and $\mathrm{I}^{-}$with the two proteins are negative at the three temperatures, which implies that this kind of binding is spontaneous. The negative value of $\Delta G^{\theta}$ for the binding of $\mathrm{F}^{-}$to the two proteins is largest, while for the binding of $\mathrm{Br}^{-}$and $\mathrm{I}^{-}$, the value of $\Delta G^{\theta}$ is smaller. This is corresponded to the values of binding constants. 
Table 2. Gibbs free energy, $\Delta G^{\theta}$, molar enthalpy, $\Delta H^{\theta}$, and molar entropy, $\Delta S^{\theta}$, for the interactions of halide ions with BSA and $\mathrm{Hb}$ in acetate buffer solutions measured by ion-selective electrode method at different temperatures.

\begin{tabular}{|c|c|c|c|c|}
\hline & $\mathrm{T} / K$ & 288.15 & 298.15 & 308.15 \\
\hline & \multicolumn{4}{|l|}{$\mathrm{F}^{-}$} \\
\hline & $\Delta G^{\theta} /\left(\mathrm{kJ} \cdot \mathrm{mol}^{-1}\right)$ & -9.77 & -9.63 & -10.00 \\
\hline \multirow[t]{3}{*}{ BSA } & $\Delta H^{\theta} /\left(\mathrm{kJ} \cdot \mathrm{mol}^{-1}\right)$ & -6.20 & -6.20 & -6.20 \\
\hline & $\Delta S^{\theta} /\left(\mathrm{J} \cdot \mathrm{mol}^{-1} \cdot \mathrm{K}^{-1}\right)$ & 12.40 & 11.51 & 12.34 \\
\hline & $\Delta G^{\theta} /\left(\mathrm{kJ} \cdot \mathrm{mol}^{-1}\right)$ & -10.45 & -10.18 & -11.08 \\
\hline \multirow[t]{4}{*}{$\mathrm{Hb}$} & $\Delta H^{\theta} /\left(\mathrm{kJ} \cdot \mathrm{mol}^{-1}\right)$ & -0.99 & -0.99 & -0.99 \\
\hline & $\Delta S^{\theta} /\left(\mathrm{J} \cdot \mathrm{mol}^{-1} \cdot \mathrm{K}^{-1}\right)$ & 32.85 & 30.84 & 32.76 \\
\hline & $\mathrm{Br}^{-}$ & & & \\
\hline & $\Delta G^{\theta} /\left(\mathrm{kJ} \cdot \mathrm{mol}^{-1}\right)$ & -8.72 & -8.88 & -9.07 \\
\hline \multirow[t]{3}{*}{ BSA } & $\Delta H^{\theta} /\left(\mathrm{kJ} \cdot \mathrm{mol}^{-1}\right)$ & -3.75 & -3.75 & -3.75 \\
\hline & $\Delta S^{\theta} /\left(\mathrm{J} \cdot \mathrm{mol}^{-1} \cdot \mathrm{K}^{-1}\right)$ & 17.26 & 17.21 & 17.27 \\
\hline & $\Delta G^{\theta} /\left(\mathrm{kJ} \cdot \mathrm{mol}^{-1}\right)$ & -9.50 & -9.64 & -9.83 \\
\hline \multirow[t]{4}{*}{$\mathrm{Hb}$} & $\Delta H^{\theta} /\left(\mathrm{kJ} \cdot \mathrm{mol}^{-1}\right)$ & -4.67 & -4.67 & -4.67 \\
\hline & $\Delta S^{\theta} /\left(\mathrm{J} \cdot \mathrm{mol}^{-1} \cdot \mathrm{K}^{-1}\right)$ & 16.77 & 16.68 & 16.75 \\
\hline & $\mathrm{I}^{-}$ & & & \\
\hline & $\Delta G^{\theta} /\left(\mathrm{kJ} \cdot \mathrm{mol}^{-1}\right)$ & -8.70 & -8.21 & -8.84 \\
\hline \multirow[t]{3}{*}{ BSA } & $\Delta H^{\theta} /\left(\mathrm{kJ} \cdot \mathrm{mol}^{-1}\right)$ & -6.07 & -6.07 & -6.07 \\
\hline & $\Delta S^{\theta} /\left(\mathrm{J} \cdot \mathrm{mol}^{-1} \cdot \mathrm{K}^{-1}\right)$ & 9.13 & 9.23 & 8.99 \\
\hline & $\Delta G^{\theta} /\left(\mathrm{kJ} \cdot \mathrm{mol}^{-1}\right)$ & -9.04 & -9.11 & -9.27 \\
\hline \multirow[t]{2}{*}{$\mathrm{Hb}$} & $\Delta H^{\theta} /\left(\mathrm{kJ} \cdot \mathrm{mol}^{-1}\right)$ & -5.80 & -5.80 & -5.80 \\
\hline & $\Delta S^{\theta} /\left(\mathrm{J} \cdot \mathrm{mol}^{-1} \cdot \mathrm{K}^{-1}\right)$ & 11.25 & 11.11 & 11.27 \\
\hline
\end{tabular}

In addition, the values of $\Delta H^{\theta}$ presented in Table 2 are very small negative, even close to zero. This shows that the electrostatic interaction between ion and protein should be accompanied with strong partial desolvation of them. The endothermic effect of the partial desolvation of solutes will compensate for the exothermic effect of electrostatic interaction to a great degree. The values of $\Delta S^{\theta}$ listed in Table 2 are all positive, which indicates that the entropic effect will be favorable for the binding of halide ions to proteins. In the interactions of halide ions with proteins, the electrostatic interaction will do negative contribution to $\Delta S^{\theta}$, while the partial desolvation accompanied will do positive contribution to $\Delta S^{\theta}$. When the latter effect is predominant, the values of $\Delta S^{\theta}$ will be positive. As the temperature increases, the secondary structure of proteins will be unfolded. This will cause the number of binding sites for halide ions increase, and resulting in the increase in the values of $\Delta S^{\theta}$. However, as is shown in Table 2, the change of the values of $\Delta S^{\theta}$ is unnoticeable with increasing temperature.
This is because that the hydration structure of solutes becomes more unstable as temperature increases, which causes $\Delta S^{\theta}$ to be decreased. As a result, the decrease in $\Delta S^{\theta}$ will compensate for the increase in $\Delta S^{\theta}$ caused by the increase in the number of the binding sites. Therefore, the change of $\Delta S^{\theta}$ with temperature increase is complex.

The smaller the ionic size, the larger the charge density. Therefore, the order of the electrostatic interaction for halide ions is $\mathrm{F}^{-}>\mathrm{Br}^{-}>\mathrm{I}^{-}$. According to hofmaister series [20], the partial desolvation effect is in the order $\mathrm{F}^{-}<\mathrm{Br}^{-}<\mathrm{I}^{-}$. The two orders are opposite and the two effects of electrostatic interaction and partial desolvation on the interaction enthalpy are also opposite. Therefore, the order of the interaction enthalpies of halide ions with the proteins studied are $\mathrm{F}^{-}<\mathrm{Br}^{-}<\mathrm{I}^{-}$. The interaction entropy of halide ions with the proteins studied come mainly from the partial desolvation but not electrostatic interaction. Therefore, the order of the interaction entropy of halide ions with the proteins studied should also be $\mathrm{F}^{-}<\mathrm{Br}^{-}<\mathrm{I}^{-}$. However, the data of interaction en- 
thalpy and entropy in Table 2 are not in the order mentioned above. This shows that the solvent reorganization has larger effect on the interaction enthalpy and entropy. If the solvent reorganization effect makes the structure of water increasing or decreasing, the interaction enthalpy and entropy will accordingly decrease or increase. The data of $\Delta H^{\theta}$ and $\Delta S^{\theta}$ in Table 2 are consistent with the above-mentioned analysis.

To further investigate the thermodynamic effect of the interactions of halide ions with BSA and $\mathrm{Hb}$, the ITC experiments were also performed. ITC experiments were carried out on a Nano-ITC titration calorimeter. To calibrate the heat effect of dilution and mixing of the titrant, a control experiment was performed by injection the titrant into the buffer alone. The dilution heat of BSA and $\mathrm{Hb}$ is negligible [24-27]. The values of the enthalpy change for the interactions of $\mathrm{F}^{-}, \mathrm{Br}^{-}$and $\mathrm{I}^{-}$with BSA and with $\mathrm{Hb}$ at $298.15 \mathrm{~K}$ from ITC measurements (Table 3) are very small, which are quite similar to the results measured by the ion-selective electrode method (Table 2). The small values of the enthalpy change indicates that the electrostatic interaction is the driven force in the interactions of $\mathrm{F}^{-}, \mathrm{Br}^{-}$and $\mathrm{I}^{-}$with $\mathrm{BSA}$ and $\mathrm{Hb}$ [22, 28-30].

\section{CONCLUSIONS}

For the purpose of this study, the binding of $\mathrm{F}^{-}, \mathrm{Br}^{-}$ and $\mathrm{I}^{-}$to $\mathrm{BSA}$ and to $\mathrm{Hb}$ were investigated by use of ion-selective electrodes, at $288.15 \mathrm{~K}, 298.15 \mathrm{~K}$ and $308.15 \mathrm{~K}$. The binding sites and the binding constants were calculated. Furthermore, the paper also discussed the variation trends for the binding parameters with increasing temperature due to the effects of temperature on the secondary structure of BSA and $\mathrm{Hb}$ and on the stability of complex of anion-protein. The thermodynamic functions of the binding were calculated according to thermodynamic relations. They show that the electrostatic interaction is the driven force in the interactions of $\mathrm{F}^{-}, \mathrm{Br}^{-}$and $\mathrm{I}^{-}$with BSA and with $\mathrm{Hb}$. At the same time, the enthalpy change of the interactions of halide ions with BSA and with $\mathrm{Hb}$ measured by ITC is in good agreement with that measured by the ion-selective electrode method. The results of the present study indicate

Table 3. Molar enthalpy, $\Delta H^{\theta}$, for the interactions of halide ions with BSA and $\mathrm{Hb}$ in acetate buffer solutions measured by ITC at $298.15 \mathrm{~K}$.

\begin{tabular}{cccc}
\hline \multirow{2}{*}{ Proteins } & \multicolumn{3}{c}{$\Delta H^{\theta} /\left(\mathrm{kJ} \cdot \mathrm{mol}^{-1}\right)$} \\
\cline { 2 - 4 } & $\mathrm{F}^{-}$ & $\mathrm{Br}^{-}$ & $\mathrm{I}^{-}$ \\
\hline BSA & -3.56 & -1.13 & -3.15 \\
$\mathrm{Hb}$ & -0.31 & -2.62 & -2.89 \\
\hline
\end{tabular}

that the method of ion-selective electrode can be successfully applied to investigate the interactions of some ions with proteins.

\section{ACKNOWLEDGEMENTS}

This work was financially supported by the National Natural Science Foundation of China (Grant No. 20673034) and the Research Fund for the Doctoral Program of Higher Education of China (Grant No. 20060476001). We also thank Prof. Yi Liu, College of Chemistry and Molecular Science, University of Wuhan, for ITC measurements.

\section{REFERENCES}

[1] Pacheco, M.T.B., Carraro, F. and Sgarbieri, V.C. (1999) Study of calcium binding to different preparations of yeast protein by using an ion selective electrode. Food Chemistry, 66, 249-252. doi:10.1016/S0308-8146(98)00252-0

[2] Carr, C.W. (1953) Studies on the binding of small anions in protein solutions with the use of membrane electrodes. IV. The binding of calcium ions in solutions of various proteins. Archieves of Biochemistry and Biophysics, 46, 424-431. doi:10.1016/0003-9861(53)90213-6

[3] Rosa, M.C.D., Castagnola, M., Bertonati, C., Galtieri, A. and Glardina, B. (2004) Physiological importance and structural basis of an additional chloride-binding sites in haemoglobin. Biochemical Journal, 380, 889-896. doi:10.1042/BJ20031421

[4] Alberty, R.A. and Marvin, H.H. (1951) The combination of bovine serum albumin with chloride ion. Journal of the American Chemical Society, 73, 3220-3223. doi:10.1021/ja01151a065

[5] Scatchard, G., Coleman, J.S. and Shan, A.L. (1957) Physical chemistry of protein solutions. VII. The binding of some small anions to bovine serum albumin. Journal of the American Chemical Society, 79, 12-20. doi:10.1021/ja01558a003

[6] Scatchard, G., Wu, Y.V. and Shen, A.L. (1959) Physical chemistry of protein solutions. VI. The binding of small anions by serum albumin. Journal of the American Chemical Society, 81, 6104-6109. doi:10.1021/ja01532a003

[7] Bojesen, E. and Bojesen, I.N. (1996) Albumin binding of long-chain fatty acids: Thermodynamics and kinetics. Journal of physical chemistry, 100, 17981-17985. doi:10.1021/jp962141m

[8] Klotz, I.M., Walker, F. M. and Pivan, R. B. (1946) The binding of organic ion by proteins. Journal of the American Chemical Society, 68, 1486-1490. doi:10.1021/ja01212a030

[9] Shrivasta, Y.H., Kanthimathi, M. and Nair, B.U. (1999) Interacton of shiff base with bovine serum albumin: Site-specific photocleavege. Biochemistry and Biophysical Research Communications, 265, 311-314. doi:10.1006/bbrc.1999.1675

[10] Hirayama, K., Akashi, S., Furuya, M. and Fukuhara, K.I. (1990) Rapid confirmation and revision of the primary structure of bovine serum albumin by ESIMS and FRIT-FAB LC/MS. Biochemistry and Biophysical Re- 
search Communications, 173, 639-646. doi:10.1016/S0006-291X(05)80083-X

[11] Taves, D.R. (1968) Evidence that there are two forms of fluoride in human serum. Nature, 217, 1050-1051. doi:10.1038/2171050b0

[12] Mangonidi, S., Stefano, C., Gombos, F. and Brunese, M. (1968) Termodinamica del legame alogeno-proteina. Archives of Stomach, 9, 237-244.

[13] Mangonidi, S., Stefano, C. and Ruggiero, M. (1969) Interaction of fluoride with serum albumin. Fluoride, 2, 91-96.

[14] Peters, T. (1985) Structure of serum albumin. Advances in Protein Chemistry, 37, 161-245.

[15] Carter, D.C. and Ho, J. X. (1994) Structure of serum albumin. Advances in Protein Chemistry, 45, 153-203. doi:10.1016/S0065-3233(08)60640-3

[16] Luehrs, D.C. and Johnson, W.C. (1986) Binding of fluoride ion to egg albumin studied with the fluoride ion selective electrode. Fluoride. 19, 86-89.

[17] Sideris, E.E., Valsami, G.N., Koupparis, M.A. and Macheras, P.E. (1999) Studies on the interaction of diflunisal ion with cyclodextrins using ion-selective electrode potentiometry. European Journal of Pharmaceutical Sciences, 7, 271-278. doi:10.1016/S0928-0987(98)00035-9

[18] Ayranci, E. (1995) Binding of iodide to bovine serum albumin and protamine studied with an ion-selective electrode. Food Chemistry, 54, 173-175. doi:10.1016/0308-8146(95)00023-C

[19] Ayranci, E. and Duman, O. (2004) Binding of fluoride, bromide and iodide to bovine serum albumin, studied with ion-selective electrodes. Food Chemistry, 84, 539-543. doi:10.1016/S0308-8146(03)00276-0

[20] Zhang, Y.J. and Cremer, P.S. (2006) Interactions between macromolecules and ions: The Hofmeister series. Current Opinion in Chemical Biology, 10, 658-663. doi:10.1016/j.cbpa.2006.09.020

[21] Ikedo, S., Shimoyamada, M. and Watanabe, K. (1996) Interaction between bovine serum albumin and saponin as studied by heat stability and protease digestion. Journal of Agriculture and Food Chemistry, 44, 792-795. doi:10.1021/if940742+

[22] Yan, C.N., Zhang, H.X., Liu, Y., Mei, P., Li, K.H. and Tong, J.Q. (2005) Fluorescence spectra of the binding reaction between paraquat and bovine serum albumin. Acta Chimica Sinica, 63, 1727-1732.

[23] Lu, Y. (2004) Enthalpic interaction for $\alpha$-amino acid with alhai metal halides in water. Chinese Journal of Chemistry, 22, 822-826. doi:10.1002/cjoc.20040220811

[24] Liang, Y., Du F., Zhou, B.R., Zhou, H., Zou, G.L., Wang, C.X. and Qu, S.S. (2002) Thermodynamics and kinetics of the cleavage of DNA catalyzed by bleomycin $\mathrm{A}_{5}$ : A microcalorimetric study. European Journal of Biochemistry, 269, 2851-2859. doi:10.1046/j.1432-1033.2002.02948.x

[25] Liang, Y., Du, F., Sanglier, S., Zhou, B.R., Xia, Y., Van Dorsselaer, A., Maechling, C., Kilhoffer, M.C. and Haiech, J. (2003) Unfolding of rabbit muscle creatine kinase induced by acid: A study using electrospray ionization mass spectrometry, isothermal titration calorimetry and fluorescence spectroscopy. Journal Biological Chemistry, 278, 30098-30105. doi:10.1074/jbc.M304050200

[26] Wettig, S.D., Wood, D.O. and Lee, J.S. (2003) Thermodynamic investigation of M-DNA: A novel metal ion-DNA complex. Journal of Inorganic Biochemistry, 94, 94-99. doi:10.1016/S0162-0134(02)00624-4

[27] Mikulecky, P.J. and Feig, A.L. (2004) Heat capacity changes in RNA folding: Application of perturbation theory to hammerhead ribozyme cold denaturation. Nucleic Acids Research, 32, 3967-3976. doi:10.1093/nar/gkh723

[28] Ross, P.D. and Subramanian, S. (1981) Thermodynamics of protein association reactions: Forces contributing to stability. Biochemistry, 20, 3096-3102. doi:10.1021/bi00514a017

[29] Khan, S.N., Islam, B., Yennamalli, R., Sultan, A., Subbarao, N. and Khan, A.U. (2008) Interaction of mitoxantrone with human serum albumin: Spectroscopic and molecular modeling studies. European Journal of Pharmaceutical Sciences, 35, 371-382. doi:10.1016/j.ejps.2008.07.010

[30] Lu, Y., Wang, G.K., Lu, X.M., Yan, C.L., Xu, M.H. and Zhang, W.W. (2010) Molecular mechanism of interaction between norfloxacin and trypsin studied by molecular spectroscopy and modeling. Spectrochimica Acta A, 75, 261-266. doi:10.1016/j.saa.2009.10.021 